Pamukkale University Journal of Social Sciences Institute

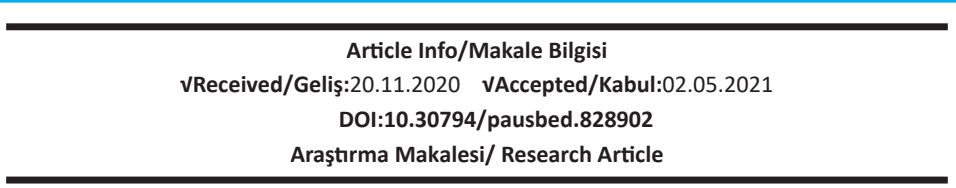

Yılmaz Yalçıner, A. ve Gelen Mert, M. B. (2021). "Estimating The Occupancy Rate of an Accommodation Business Using Artificial Neural Networks" Pamukkale Üniversitesi Sosyal Bilimler Enstitüsü Dergisi, Sayı 47, Denizli, ss. 209-218.

\title{
ESTIMATING THE OCCUPANCY RATE OF AN ACCOMMODATION BUSINESS USING ARTIFICIAL NEURAL NETWORKS
}

\author{
Ayten YILMAZ YALÇINER*, Mine Büşra GELEN MERT**
}

\begin{abstract}
Tourism is one of the sectors that is highly influential in countries' economy. Tourism activity can be realized for many reasons, especially for business or cultural purposes. Such as Turkey, for countries where tourism is intensively carried out, It is very important to predict tourism demand. Many reasons, such as the determination of the workforce to be employed in tourism and the determination of the accommodation infrastructure needed, have increased the efforts to estimating the demands in the tourism sector in advance. In this study, the demand for tourism is handled in terms of accommodation establishments. It is aimed to estimate the occupancy rate for a accommodation business in Sakarya. Several factors that have an effect on the occupancy rate have been detected and it has been ensured that the occupancy rate can be predicted with a high estimation rate by using artificial neural networks which are one of the artificial intelligence techniques.
\end{abstract}

Keywords: Artificial neural networks, Occupancy rate estimation, Artificial intelligence, Accommodation establishments, Tourism.

\section{YAPAY SINIR AĞLARI KULLANARAK BİR KONAKLAMA IŞLETMESININ DOLULUK ORANININ TAHMINI}

Özet

Turizm, ülkelerin ekonomisinde oldukça etkili olan sektörlerden biridir. Türkiye gibi iş veya kültürel başta olmak üzere birçok amaçla turizm faaliyetinin yoğun olarak gerçekleştirildiği ülkelerde turizm talebinin öngörülebilmesi oldukça önemlidir. Turizmde istihdam edilecek işgücünün ve ihtiyaç duyulan konaklama altyapısının tespit edilebilmesi gibi birçok sebep, turizm sektöründe taleplerin önceden tespit edilebilmesine yönelik çalışmaları son yıllarda arttırmıştır. Bu çalışmada turizme olan talep, konaklama işletmeleri açısından ele alınmaktadır. Sakarya'da faaliyet gösteren bir konaklama işletmesi için doluluk oranının tahmin edilmesi hedeflenmektedir. Doluluk oranı üzerinde etkisi olan çeşitli faktörler belirlenmiş ve yapay zekâ tekniklerinden biri olan yapay sinir ağları kullanılarak doluluk oranının önceden yüksek bir tahmin oranı ile öngörülebilmesi sağlanmıştır.

Anahtar kelimeler: Yapay sinir ağları, Doluluk oranı tahmini, Yapay zekâ, Konaklama işletmeleri, Turizm.

\footnotetext{
*Assistant Professor, Sakarya University, Department of Industrial Engineering, Faculty of Engineering, SAKARYA. e-posta:ayteny@sakarya.edu.tr, (https://orcid.org/0000-0001-8160-812X)

**PhD student, Sakarya University, Program of Industrial Engineering, Institute of Natural Sciences, SAKARYA.

e-posta:minebusra92@gmail.com, (https://orcid.org/0000-0001-7033-889X
} 


\section{Pamukkale Üniversitesi Sosyal Bilimler Enstitüsü Dergisi, Sayı 47, Kasım 2021 A. Yılmaz Yalçıner,}

\section{B. Gelen Mert}

\section{INTRODUCTION}

The tourism sector, which is an important source of income for the economies of the country, is a strategic factor in terms of creating employment, providing foreign currency inflow, high investment rate, high added value and providing dynamism to other sectors (agriculture, transportation, food, service, logistics, etc.) is important. The tourism sector is one of those that has a great impact on the economies of the country and is rapidly affected by economic changes. Businesses in this sector are more sensitive to environmental factors than businesses in other sectors within the scope of competitiveness. Demand forecasting, which is very important for the tourism sector due to the fact that the demand is very flexible and tourism services cannot be stocked; will be able to support managers in making the right decisions and using their resources efficiently (AKTOB, 2014: https://docplayer.biz.tr/7919989-Turizm-sektorunun-yapisi-buyuklugu-ve-ekonomiye-katkisi.html; Güngör and Çuhadar 2005:84-98; Zhang vd. 2018: 4351)

According to the data of the World Travel and Tourism Council (WTTC) in 2019, the tourism and travel industry creates $10 \%$ of the total employment by providing direct and indirect job opportunities to 330 million people worldwide. In this sense, one out of every ten people in the world is employed in the tourism sector (World Travel and Tourism Council, 2020: https://wttc.org/en-gb/). The prevalence of experiencing the four seasons of tourism opportunities in countries such as Turkey and the sector is a little bit more and have an important role in terms of investments. Referring tourism statistics Turkey in 2018 Turkey with 45.8 million the number of tourists between the countries with the most number of tourist arrivals has become the sixth country in the world. Similarly, in terms of tourism income, it ranked 6th in Europe with an income of 25.2 billion dollars (KTB, 2019: https://yigm.ktb.gov.tr/Eklenti/69320,turizmistatistikleri2019-4pdf.pdf?0). (The comments here are based on 2018 data, as the tourism sector has suffered great economic and social losses due to the COVID-19 pandemic). In order to benefit from the advantages of the sector with such a large and effective potential, it is necessary to carefully consider the critical elements in the sector. In this context, one of the important elements is the accurate realization of the predictions. Foresighting possible future developments in the sector, estimating the demand for optimal capacity planning activities and calculating the occupancy rate accordingly, and effectively realizing new investments and risk management for these investments in the long and short term are of strategic importance for the sector. In order to take advantage of the advantageous features of tourism sector, it is necessary to make forward-looking planning, and to make this planning, demand estimations created with accurate data are required.

Due to the general characteristics of the sector, there are frequent fluctuations in demand and predicting demand can become a complex and difficult problem. In connection with the demand for accommodation establishments, especially in tourism, the occupancy rate forecast is of great importance in many issues such as service quality, costs, and inter-company competition. Costs can be calculated in advance by forecasting the occupancy rate of accommodation businesses. Furthermore, in case of low occupancy rate, many measures can be taken to carry out promotions, decrease in hotel prices and perform advertising activities. In forecast studies, various methods such as Regression Analysis, Trend Forecast Methods, Simple Exponential Correction and Artificial Neural Networks can be used. Artificial neural networks, which are one of the artificial intelligence techniques, can be applied to problems with large size, non-linear and defective data (Karaatlı et al., 2012: 87100).

Based on this importance, in this study, it is aimed to forecast the occupancy rate on a daily basis for a hotel operating in Sakarya. Using the records of the hotel's past daily occupancy rates, artificial neural networks were used in the forecast. Seven input values, including special days, USD exchange rates, days, seasons, months, CPI and clicks were determined. The occupancy rate of the hotel was determined as the output of artificial neural networks. Since the study was not conducted in a city with intense tourism activities, it was preferred to address common values that can be easily used by the accommodation business operating in each region instead of focusing on the location of the enterprise. An artificial neural network was created with the determined seven 


\section{B. Gelen Mert}

input values and occupancy rate output values. MSE (mean square error) and MAD (mean absolute deviation) values were taken into consideration in the evaluation of the results. When the calculated error rates were examined, it was seen that artificial neural networks performed successfully in estimating the hotel occupancy rate.

\section{LITERATURE REVIEW}

There are various studies conducted in the literature to forecast the hotel occupancy rate. Chow et al. (1998: 55-80) conducted the Box-Cox conversion function, the ARIMA and ARIMA transfer function model using to forecast the hotel occupancy rate for international hotels in Taiwan.

Andrew et al. (1990: 173-182) applied BoxJenkins and exponential smoothing methods to estimate the hotel occupancy rate and achieved high forecast performance. Law (2004: 71-77), using the developed extrapolative time series forecasting technique, and by using the hotel occupancy rate information officially published in Hong Kong, the occupancy rate forecast was performed and a successful forecast performance was achieved.

Zakhary (2010: 241-251) et al. used Monte Carlo simulation by taking advantage of past booking cancellations, reservations, group bookings and length of stay information to forecast occupancy rate for a hotel in Egypt. Soysal and Ömürgönülşen (2010: 128-136) used Moving Average, Simple Exponential Smoothing, Holt and Winter methods to provide six-month estimates for the number of tourists visiting certified business facilities in Turkey, in 2008. Wu et al. (2010: 426-438) used a proposed data mining technique called independent component analysis (ICA) to determine the factors that determine the hotel occupancy rate.

Baldigara and Koic (2015: 121), the hotel occupancy rate in the Croatian hotel industry was calculated using the seasonal Naive model, the Holt-Winters exponential model and the seasonal autoregressive integrated moving average model. Çuhadar and Kervankıran (2016: 343-352), using the number of monthly domestic and foreign tourists entering the accommodation establishments operating in Nevşehir between 2010-2015 and using the Simple Seasonal Model, Holt-Winters Model, Declining Trend Model, Exponential Trend Model, Additive-Seasonal/Decreasing Trend Model and ARIMA model were determined the demand for tourism.

Neural Networks, Ridge Regression, Kernel Ridge Regression methods were used by Caicedo-Torres and Payares (2016: 201-211) for the daily forecast of hotel occupancy rate. Schwartz et al. (2016: 267-285), incorporating the competitive set prediction into the genetic algorithm or the simple linear regression model, predicted the performance of the hotel occupancy rate forecast has been determined to increase. Pan and Yang (2017: 957-970) forecasted the weekly hotel occupancy rate by utilizing search engine queries, website traffic and weekly weather information and using the ARMAX model. Warren (2017: 18-37) estimated the occupancy rate of the hotel in the United States by moving average method, simple exponential correction, SARIMA and multiplicative Holt-Winters methods. Assaf and Tsionas (2019: 439-449) proposed the use of VARs (Large Vector Autoregressions) models based compressed Regression for the hotel occupancy rate estimation and used artificial neural networks to make the models more flexible. Aliyev et al. (2019: 793), fuzzy rule-based system model ve fuzzy c-means clustering algorithm were developed and were used applied on the problem of forecasting the hotel occupancy rate.

Some studies in the literature on determining the occupancy rate in tourism demand and accommodation establishments are included in Table 1. 
Pamukkale Üniversitesi Sosyal Bilimler Enstitüsü Derqisi, Sayı 47, Kasım 2021 A. Yılmaz Yalcıner,

\section{B. Gelen Mert}

Table 1: Studies on tourism demand and occupancy rate estimation using an artificial neural network

\begin{tabular}{|c|c|c|}
\hline Reference & Using Inputs & Subject of study \\
\hline Law (1998: 234-239) & $\begin{array}{l}\text { Number of tourists, the average length of stay, the number } \\
\text { of hotels and the number of rooms }\end{array}$ & $\begin{array}{l}\text { Occupancy rate of Hong Kong } \\
\text { hotels has been estimated. }\end{array}$ \\
\hline $\begin{array}{l}\text { Law and Au (1999: 89- } \\
\text { 97) }\end{array}$ & $\begin{array}{l}\text { Service price, average hotel rate, foreign } \\
\text { exchange rate, population, marketing expenses, and gross } \\
\text { domestic expenditure }\end{array}$ & $\begin{array}{l}\text { An artificial neural network model } \\
\text { was used to estimate Japan's } \\
\text { travel demand to Hong Kong. }\end{array}$ \\
\hline $\begin{array}{l}\text { Çuhadar and Kayacan } \\
\text { (2005: 24-30) }\end{array}$ & $\begin{array}{l}\text {-The monthly number of ministry-certified facilities in } \\
\text { Turkey, } \\
\text {-The number of beds monthly in accommodation facilities } \\
\text { that licensed by The Ministry of Culture and Tourism in } \\
\text { Turkey, } \\
\text {-The monthly total number of foreign tourists staying in } \\
\text { accommodation establishments licensed by The Ministry } \\
\text { of Culture and Tourism in Turkey, } \\
\text {-The total number of overnight stays per month of foreign } \\
\text { tourists staying in ministry-certified accommodation } \\
\text { establishments in Turkey } \\
\text {-Average monthly duration of stay of foreign tourists in } \\
\text { ministry-certified accommodation establishments in Turkey }\end{array}$ & 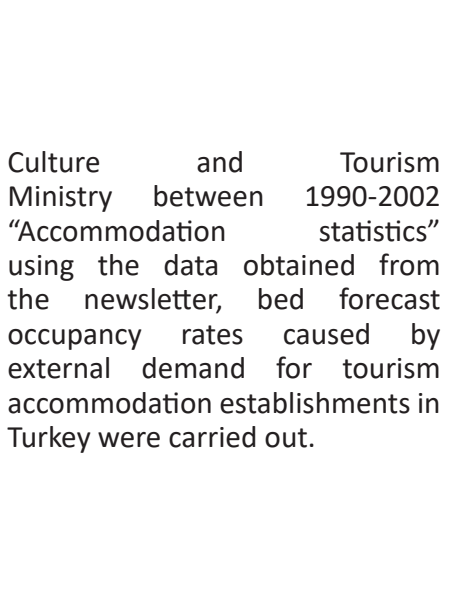 \\
\hline $\begin{array}{l}\text { Constantino et al. } \\
(2016: 113-124)\end{array}$ & $\begin{array}{l}\text { exchange rate, gross domestic product per capita, } \\
\text { harmonized index of consumer prices }\end{array}$ & $\begin{array}{l}\text { Tourism demand is determined for } \\
\text { Mozambique. }\end{array}$ \\
\hline $\begin{array}{l}\text { Golcuk et al. (2020: } 66- \\
\text { 70) }\end{array}$ & $\begin{array}{l}\text { Total number of people incoming to facility, the total } \\
\text { number of overnight stays of the people staying in the } \\
\text { hotels, the average monthly stay of the people staying in } \\
\text { hotels }\end{array}$ & $\begin{array}{l}\text { Utilizing the statistics of the } 2000- \\
2018 \text { year stay in Turkey, the hotel } \\
\text { occupancy rate estimate is made. }\end{array}$ \\
\hline
\end{tabular}

When the studies are examined, it is seen that the majority of the studies focus on obtaining a general estimate occupancy or tourism demand by evaluating many accommodation establishments in a province, a region or across the country. In this study, it is aimed to obtain a business-based occupancy rate estimation result by focusing on the business instead of a comprehensive estimate. In this framework, 7 criteria that are effective on the occupancy rate have been determined, and it is aimed that many businesses can easily use these criteria within their own structure to achieve a successful forecast performance.

\section{ARTIFICIAL NEURAL NETWORK}

ANN is an artificial intelligence technique consisting of artificial neural cells, indicating non-linear relationships between inputs and outputs (Taşdelen et al., 2009: 5-12). ANN is based on the structure and working principle of biological nerve cells in the human brain. In ANN, intracellular communication provided by synapses in the real nerve cells is provided by the collecting function, whereas the intracellular information transfer process performed by using axons in the real nerve cells is provided by using the activation function (Öztemel, 2003: 57). ANN is composed of five basic components. These components are inputs, weights, aggregation function, activation function and output (Kaynar et al., 2011: 463-474). Figure 1 shows the structure of an artificial nerve cell composed of $\mathrm{m}$ inputs. Here $\mathrm{Wi}(\mathrm{i}=1,2, \ldots, \mathrm{m})$ represents the weights used in the application and $\mathrm{b}$ represents the bias value. 


\section{B. Gelen Mert}

Information flow

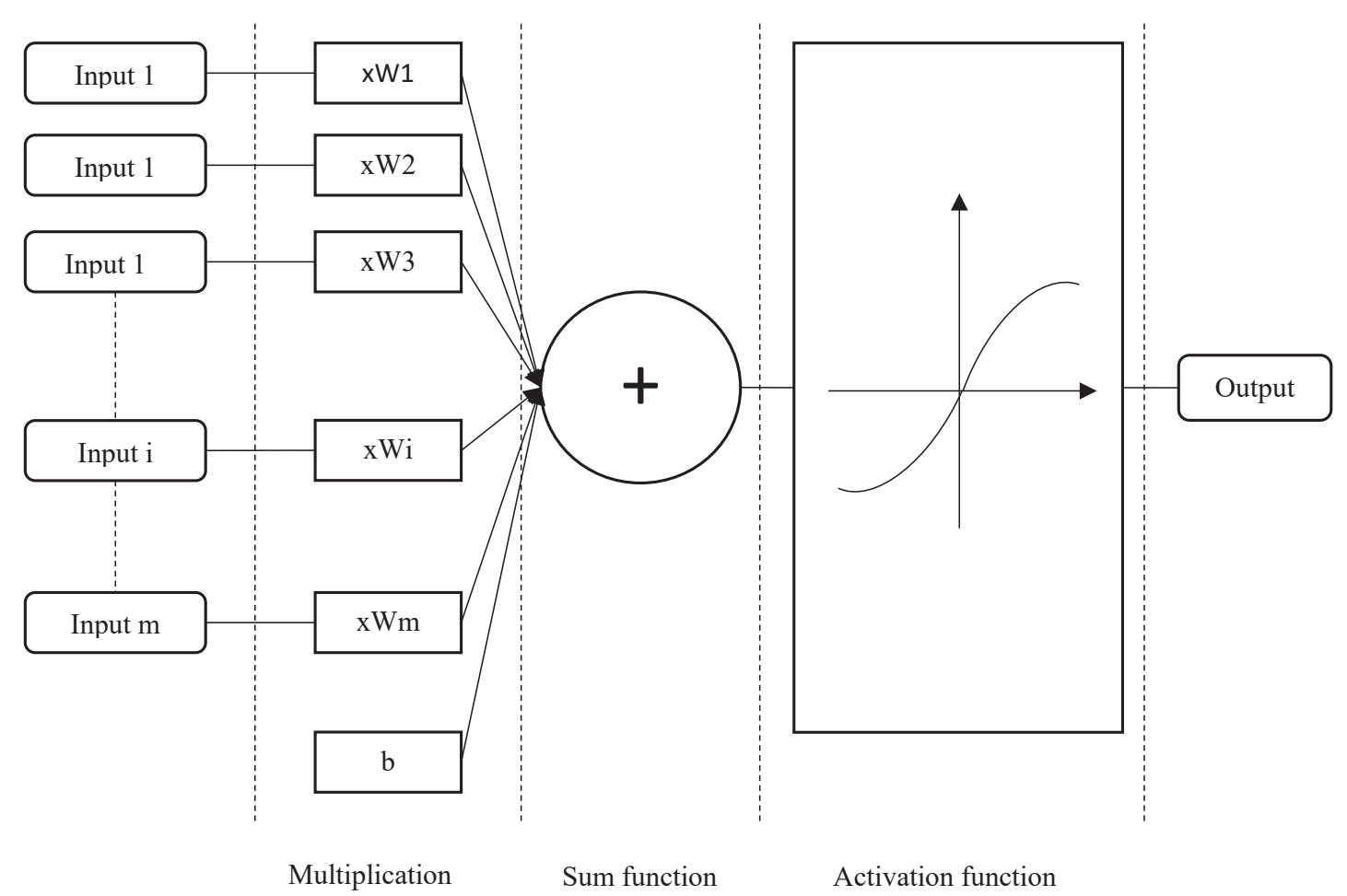

Figure 1: An artificial neuron model (Suzuki, 2011)

When there are only input and output layers in the artificial nerve cell, it is called as a single layer sensor and the hidden layer is added to these layers and it is called multi-layer sensor (Arı and Berberler, 2017: 55-73). The general structure of the ANN is to perform the learning process of the artificial nerve cell with the available data and to perform the task given by using what they have learned (Kaynar et al., 2011: 463-474). In ANN applications, data from outside form creates inputs, whereas the effect of inputs or process element in another layer constitutes the weights. The data multiplied by the weights initially determined are combined with the sum function. The result from the sum function is converted to output using the activation function. Various network types, addition and activation function types are used in ANN applications. In addition, the number of neurons used in ANN may also vary. The number of neurons used, network structure and function types play a decisive role in the working performance of the technique. Because of its ease of understanding and mathematically proven work, the feedforward backpropagation algorithm is a frequently preferred algorithm for the training of ANN (Kaynar and Taştan, 2009).

\section{NUMERICAL EXAMPLE AND TEST}

The application was carried out by providing the accommodation information of the hotel as a result of the request to establish a system that can predict the occupancy rate of a 20-room boutique hotel, which started operations in Sakarya in 2017. It was aimed to estimate the daily occupancy rate of this hotel and artificial neural network technique was applied. With the start of operation of the hotel, accommodation data for 718 days of active operation was obtained. All of the days with full knowledge of occupancy rate were evaluated within the framework of 7 criteria which are thought to have an effect on the occupancy rate. These criteria include; special days, USD exchange rate, day, season, month, CPI and click criteria. According to special days criteria; If one of the Valentine's Day, New Year's Day, one of the official and religious festivals is scored as 2, otherwise it is scored as 1 . On the basis of the USD exchange rate, the day to be evaluated takes the dollar dry value for that day. While determining the value of the day criterion, if the evaluated day is on weekdays, it is scored as 1 and the weekend value is 2 . The value of the season criterion is determined to be 1 if the day to be evaluated is 1 in the spring 


\section{B. Gelen Mert}

season, 2 in the summer and 3 in the autumn season and 4 in the winter season. While determining the value of the month criterion, the evaluated day was scored as 1 point in the first month of the year, 2 points in the second month and 12 points in the twelfth month. While evaluating the day according to CPI, the previous month's CPI value was used. When determining the value of the click criterion, the number of clicks on the hotel's website was used daily. On day basis, the values of the seven input parameters for 15 days are shown in Table 2.

Table 2: Values of seven entries of 15 days and hotel occupancy rate information

\begin{tabular}{|c|c|c|c|c|c|c|c|c|}
\hline Date & $\begin{array}{l}\text { Special } \\
\text { Days }\end{array}$ & $\begin{array}{c}\text { USD } \\
\text { Exchange } \\
\text { Rate }\end{array}$ & Day & Season & Moon & CPI & Clicks & $\begin{array}{c}\text { Occupancy } \\
\text { Rate }\end{array}$ \\
\hline 7.08.2017 & 1 & 3.5291 & 1 & 2 & 8 & 0.15 & 300 & 0.34 \\
\hline 9.08 .2017 & 1 & 3.5376 & 3 & 2 & 8 & 0.15 & 270 & 0.54 \\
\hline 10.08.2017 & 1 & 3.5418 & 4 & 2 & 8 & 0.15 & 180 & 0.74 \\
\hline 11.08 .2017 & 1 & 3.5369 & 5 & 2 & 8 & 0.15 & 555 & 0.34 \\
\hline 14.08.2017 & 1 & 3.5257 & 1 & 2 & 8 & 0.15 & 365 & 0.47 \\
\hline 15.08 .2017 & 1 & 3.5352 & 2 & 2 & 8 & 0.15 & 150 & 0.47 \\
\hline 16.08 .2017 & 1 & 3.5156 & 3 & 2 & 8 & 0.15 & 390 & 0.61 \\
\hline 17.08 .2017 & 1 & 3.5254 & 4 & 2 & 8 & 0.15 & 190 & 0.74 \\
\hline 18.08.2017 & 1 & 3.5185 & 5 & 2 & 8 & 0.15 & 245 & 0.34 \\
\hline 19.08.2017 & 1 & 3.5185 & 6 & 2 & 8 & 0.15 & 380 & 0.54 \\
\hline
\end{tabular}

The application of artificial neural networks was carried out using the neural network plug-in included in the MATLAB program. Normalization process with Eq. (1) was applied to the accommodation data before the application.

$$
n v=0.8 * \frac{\left(y_{i j}-\min _{j}\right)}{\left(\max _{j}-\min _{j}\right)}+0.1
$$

$$
\begin{aligned}
& n_{v}=\text { normalized value } \\
& y_{i j}=\text { data } \text { with row number } i \text { column number } j \\
& \min _{j}=\text { minimum value of column } j \\
& \max _{j}=\text { maximum value of column } j
\end{aligned}
$$

After the normalization process, the data became suitable for use in the program. $90 \%$ of the data consisting of 718 lines were used as training set, while $10 \%$ were used as test data for testing artificial neural networks. In practice, Feed-forward backprop for network type, TRAINLM for training function, LEARNGDM for adaption learning function, MSE for performance function, TANSIG for transfer function, 1 for number of layers and 10 neurons for number of neurons were used. The number of iterations used in the training of the network is determined as 1000 ephocs. 


\section{B. Gelen Mert}

Within the framework of the seven input parameters used, ANN was trained. The training was completed in 42 ephocs and as a result, the regression graph obtained from the MATLAB program neural network plug-in is shown in Figure 2.
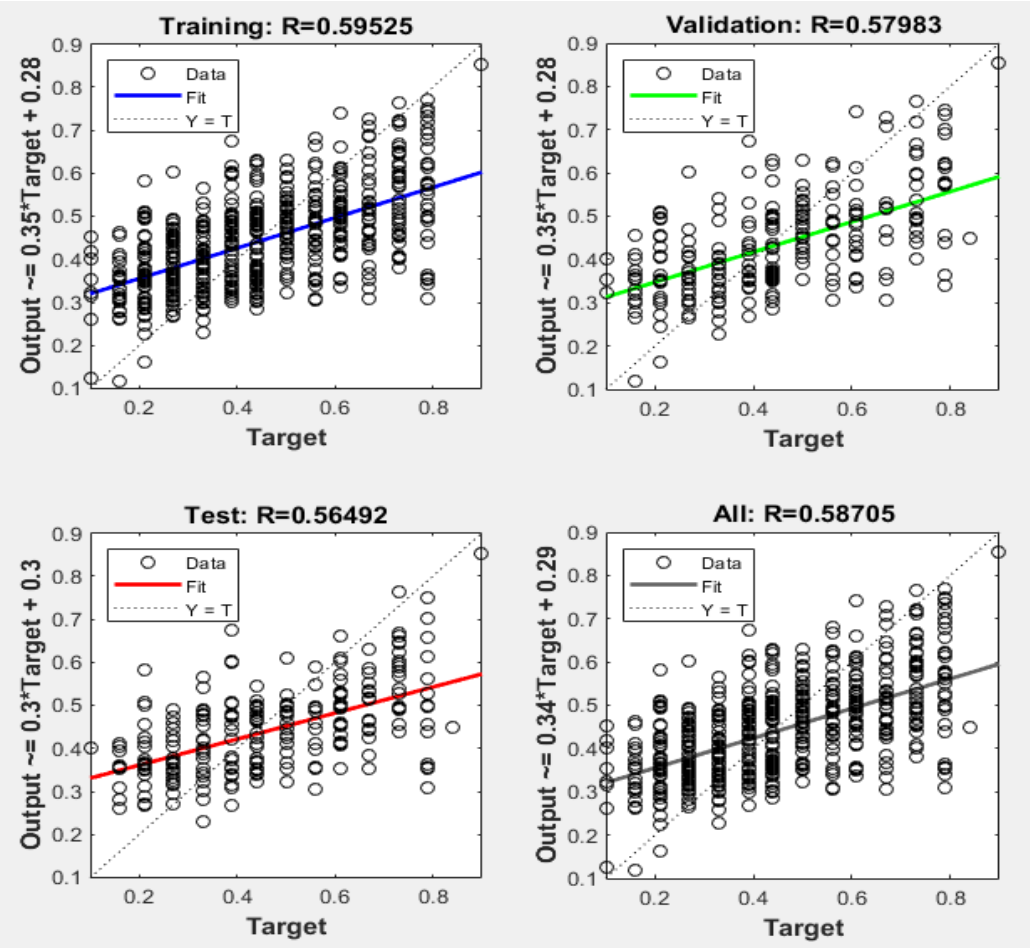

Figure 2: Screenshot of the regression graphs of the educational outputs of ANN

When the graphics shown in Figure 2 are examined; as a result of the training, testing and verification evaluations, it was seen that the overall performance of ANN was approximately $59 \%$. After the training process, the network was tested using test data to test the ANN. The actual occupancy rates and the occupancy forecastes rate obtained by ANN are shown in the graph in Figure 3.

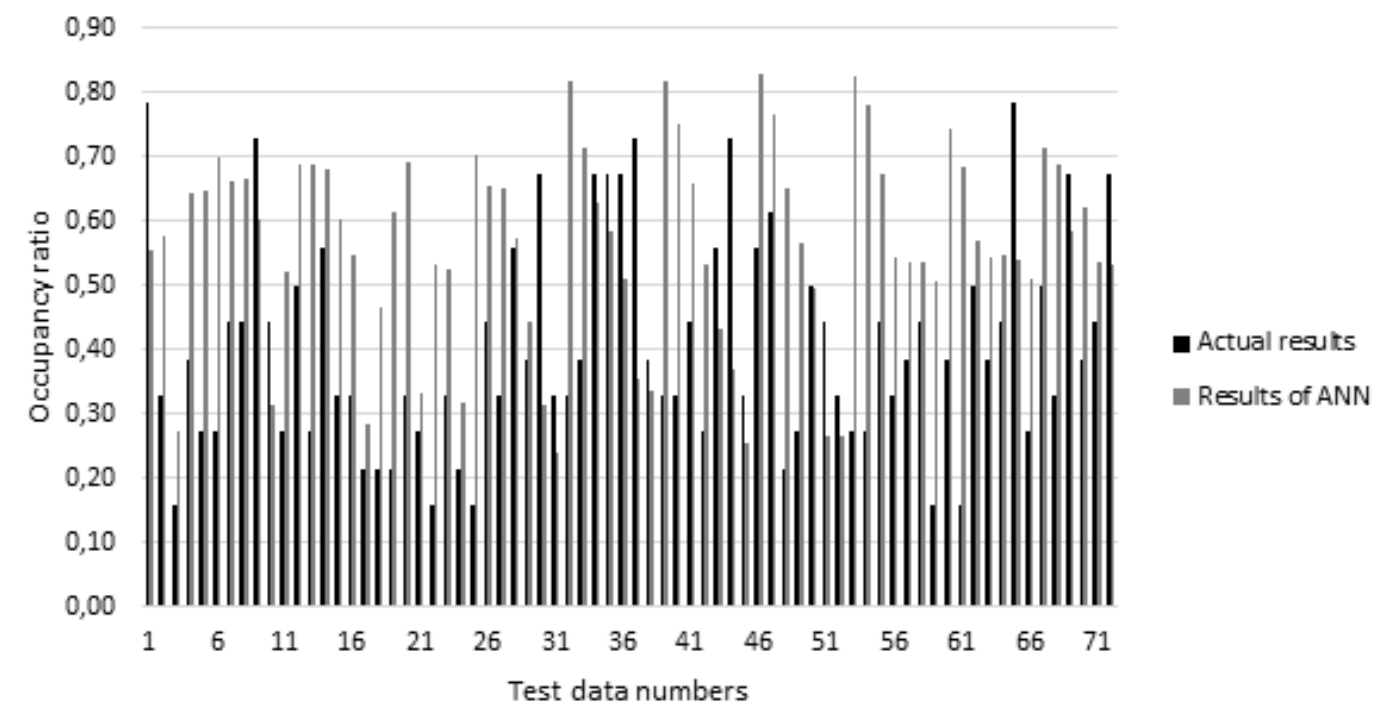

Figure 3: Comparison of actual results and results of ANN 


\section{B. Gelen Mert}

When the graph in Figure 3 is analyzed, it is seen that some forecast values obtained as result of ANN remain below the actual occupancy rate values. It was found that most of the results were graphically similar.

The error rate was calculated in order to determine the performance of the ANN on the hotel occupancy rate estimation problem. The comparison of the estimation results obtained with ANN with the actual occupancy rates is shown in Table 3 in terms MSE (mean square error) and MAD (mean absolute deviation) error rates.

Table 3: Comparison of the difference between Results of ANN and Actual results with error rates

\begin{tabular}{|c|c|}
\hline \multicolumn{2}{|c|}{ ERROR RATE CALCULATION METHODS } \\
\hline MSE & MAD \\
\hline $8 \%$ & $24 \%$ \\
\hline
\end{tabular}

According to the results of Table 3, it is seen that ANN has a high performance in terms of MSE and MAD values in forecasting hotel occupancy rate.

\section{CONCLUSION AND FUTURE WORK}

In the tourism sector, which is an important source of income for the economies of countries, forecasting studies (especially intelligent forecasting methods that present more consistent results today) will guide tourism business managers, local governments and all relevant institution managers in their future decision-making and planning studies.

In this study, which was carried out with the aim of supporting accommodation businesses in the tourism sector in their estimation and planning processes, forecasted the occupancy rate for a hotel operating in Sakarya using artificial neural networks. In application, the occupancy rates of the hotel in the past days were used as output values and special days, USD currency, day, season, month, CPI and click values were used as input values. In order to be able to use the application in many accommodation establishments, variables which have common knowledge in accommodation establishments were preferred while determining study inputs. A part of the data set was used for the training of ANN. After the completion of the network training, the occupancy rate was forecasted for 72 days. Artificial neural networks were applied by taking 718 days of operational data and the hotel occupancy rate was estimated.

In order to evaluate the forecast results obtained, MSE and MAD error calculation methods were used to compare the current situation and ANN results. The results show that in the calculations made by the MSE and MAD methods, the ANN has successful performance in the estimation of the hotel occupancy rate. It is possible to achieve more successful forecast performance by obtaining more accommodation data.

The results obtained were evaluated with MSE (with the result of $8 \%$ ) and MAD (with the result of 24\%). In artificial neural networks, it is possible to achieve higher learning performance with more data in the learning process of the network. Thus, it is possible to achieve a higher success in the prediction performance of artificial neural networks and to make predictions with lower error rates than obtained in the study. In this study, the usability of artificial neural networks in occupancy rate estimation has been demonstrated by using 7 determined inputs.

As a future study, if more input values and data for more years are obtained and a similar model is run again, it may be possible to obtain a higher prediction rate, i.e. lower MSE and MAD performance values. Alternatively, it is possible to work with different variables to analyze the estimation efficiency. In addition, testing the value obtained in the operated ANN model under different constraints such as different city, different hotel size can be presented as a future study proposal. Aternatively, by obtaining data such as comments and likes of tourists or travel enthusiasts, especially on social media, predictions or inferences can be made in the accommodation sector thanks to text mining.

As another future study, several of the artificial intelligence techniques can be applied as a hybrid by obtaining more accommodation data to improve performance in predicting hotel occupancy rate. However, It is important 


\section{B. Gelen Mert}

to eliminate uncertainties that may occur due to demand elasticity in accommodation businesses. In this context, a heuristic algorithm can be developed based on the criteria that cause / may cause imbalance between seasonal demands and different room options.

\section{REFERENCES}

AKTOB, (2014). 2023'e Doğru Türkiye'de Turizmin 100 Yılı, Araştırma Raporu. Accessed date: 02.02.2021, https:// docplayer.biz.tr/7919989-Turizm-sektorunun-yapisi-buyuklugu-ve-ekonomiye-katkisi.html.

Aliyev, R., Salehi, S., and Aliyev, R. (2019). “Development of Fuzzy Time Series Model for Hotel Occupancy Forecasting", Sustainability, 11/3, 793

Andrew, W. P., Cranage, D. A., and Lee, C. K. (1990). "Forecasting hotel occupancy rates with time series models: An empirical analysis", Hospitality Research Journal, 14/2, 173-182.

Arı, A., and Berberler, M. E. (2017). "Yapay Sinir Ağları ile Tahmin ve Sınıflandırma Problemlerinin Çözümü Iç̧in Arayüz Tasarımı", Acta INFOLOGICA, 1/2, 55-73.

Assaf, A. G., and Tsionas, M. G. (2019). "Forecasting occupancy rate with Bayesian compression methods", Annals of Tourism Research, 75, 439-449.

Baldigara, T., and Koic, M. (2015). “Modelling Occupancy Rates in Croatian Hotel Industry", International Journal of Business Administration, 6/3, 121.

Caicedo-Torres, W., and Payares, F. (2016). "A machine learning model for occupancy rates and demand forecasting in the hospitality industry", Ibero-American Conference on Artificial Intelligence, 201-211.

Chow, W. S., Shyu, J. C., and Wang, K. C. (1998). "Developing a forecast system for hotel occupancy rate using integrated ARIMA models", Journal of international hospitality, leisure \& tourism management, 1/3, 55-80.

Constantino, H. A., Fernandes, P. O., and Teixeira, J. P. (2016). Tourism demand modelling and forecasting with artificial neural network models: the Mozambique case study. Tékhne, 14(2), 113-124.

Çuhadar, M., and Kayacan, C. (2005). "Yapay Sinir Ağları Kullanılarak Konaklama İşletmelerinde Doluluk Oranı Tahmini: Türkiye'deki Konaklama İşletmeleri Üzerine Bir Deneme”, Anatolia: Turizm Araştırmaları Dergisi, 16/1, 24-30.

Çuhadar, M., and Kervankıran, İ. (2016). "Nevşehir ili konaklama işletmelerine yönelik turizm talebinin analizi, modellenmesi ve tahminleri”, Muğla Sıtkı Koçman Üniversitesi İktisadi Ve İari Bilimler Fakültesi Ekonomi Ve Yönetim Araştırmaları Dergisi, 5/2, 343-352.

Golcuk, A., Yasak, M. S., and Dalmizrak, M. B. (2020). “Forecasting with Multilayer Perceptron Algorithm the Occupancy Rate of Accommodation Establishmentsin Turkey", International Journal of Intelligent Systems and Applications in Engineering, 8/2, 66-70.

Güngör, İ., and Çuhadar, M.. (2005). “Antalya Iline Yönelik Alman Turist Talebinin Yapay Sinir Ağları Yöntemiyle Tahmini “, Gazi Üniversitesi Ticaret ve Turizm Eğitim Fakültesi Dergisi, 1, 84-98.

Karaatlı, M., Helvacıoğlu, Ö. C., Ömürbek, N., and Tokgöz, G. (2012). "Yapay sinir ağları yöntemi ile otomobil satış tahmini", Uluslararası Yönetim iktisat ve Iş̧letme Dergisi, 8/17, 87-100.

Kaynar, O., and Taştan, S. (2009). "Zaman Serisianalizinde MLP Yapay Sinir Ağları ve Arıma Modelinin Karşılaştırılması”, Erciyes Üniversitesi İktisadi ve Idari Bilimler Fakültesi Dergisi, 33, 161-172.

Kaynar, O., Taştan, S., and Demirkoparan, F. (2011). "Yapay sinir ağlari ile doğalgaz tüketim tahmini”, Atatürk Üniversitesi Iktisadi ve Idari Bilimler Dergisi, 25, 463-474.

KTB, (2019). T.C. Kültür ve Turizm Bakanlığı Yatırım ve İşletmeler Genel Müdürlüğü, 2019 Turizm İstatistikleri Raporu. Accessed date: 02.02.2021, https://yigm.ktb.gov.tr/Eklenti/69320,turizmistatistikleri2019-4pdf. pdf?0.

Law, R. (1998). "Room occupancy rate forecasting: a neural network approach", International Journal of Contemporary Hospitality Management, 10/6, 234-239.

Law, R. (2004). "Initially testing an improved extrapolative hotel room occupancy rate forecasting technique", Journal of Travel \& Tourism Marketing, 16/2-3, 71-77. 


\section{B. Gelen Mert}

Law, R., and Au, N. (1999). "A neural network model to forecast Japanese demand for travel to Hong Kong", Tourism Management, 20/1, 89-97.

Öztemel, E. (2012). Yapay Sinir Ağları, 3. Baskı, Papatya Yayıncılık, İstanbul, 57.

Pan, B., and Yang, Y. (2017). "Forecasting destination weekly hotel occupancy with big data", Journal of Travel Research, 56/7, 957-970.

Schwartz, Z., Uysal, M., Webb, T., and Altin, M. (2016). "Hotel daily occupancy forecasting with competitive sets: a recursive algorithm", International Journal of Contemporary Hospitality Management, 28/2, 267-285.

Soysal, M., and Ömürgönülşen, M. (2010). “Türk Turizm Sektöründe Talep Tahmini Üzerine Bir Uygulama”, Anatolia: Turizm Araştırmaları Dergisi, 21/1, 128-136.

Suzuki, K., (2011). Artificial neural networks: methodological advances and biomedical applications, In Tech, Croatia, 3-18.

Taşdelen, B., Helvaci, S., Kaleağasi, H., and Özge, A. (2009). "Artificial neural network analysis for prediction of headache prognosis in elderly patients", Turkish Journal of Medical Sciences, 39/1, 5-12.

Warren, R. N. (2017). Occupancy forecasting methods and the use of expert judgement in hotel revenue management, Graduate Theses and Dissertations, lowa State University, 18-37.

World Travel and Tourism Council, (2020). Accessed date: 02.02.2021, https://wttc.org/en-gb/.

Wu, E. H., Law, R., and Jiang, B. (2010). "Data mining for hotel occupancy rate: an independent component analysis approach", Journal of travel \& tourism marketing, 27/4, 426-438.

Zakhary, A., El Gayar, N., and Ahmed, S. E. O. H. (2010). "Exploiting neural networks to enhance trend forecasting for hotels reservations", Workshop on Artificial Neural Networks in Pattern Recognition, 241-251.

Zhang, M., Li, J., Pan, B., and Zhang, G. (2018). "Weekly Hotel Occupancy Forecasting of a Tourism Destination", Sustainability, 10/12, 4351.

\section{Beyan ve Açıklamalar (Disclosure Statements)}

1. Bu çalışmanın yazarları, araştırma ve yayın etiği ilkelerine uyduklarını kabul etmektedirler (The authors of this article confirm that their work complies with the principles of research and publication ethics).

2. Yazarlar tarafından herhangi bir çıkar çatışması beyan edilmemiştir (No potential conflict of interest was reported by the authors).

3. Bu çalışma, intihal tarama programı kullanılarak intihal taramasından geçirilmiştir (This article was screened for potential plagiarism using a plagiarism screening program).

4. Bu makale için etik kurul izni gerekmemektedir (Ethics committee permission is not required for this article). 